\section{Trans-science as a vocation}

\section{Gil Eyal}

Columbia University, USA
Journal of Classical Sociology 2019, Vol. 19(3) 254-274 (C) The Author(s) 2019

Article reuse guidelines: sagepub.com/journals-permissions DOI: 10.1 I77/I468795X 1985। 377 journals.sagepub.com/home/jcs

\begin{abstract}
This paper compares Weber's argument in "Science as a vocation," with Physicist Alvin Weinberg's discussion of the distinction between science and "trans-science," as two contrasting blueprints for boundary-work. It argues that Weber's empirical reasons for separating the scientific discussion of means and the extra-scientific discussion of ends - namely, the thesis of "disenchantment" - no longer serves as a useful approach to understanding the growth of "transscience" or "expertise" over the last century. It advances an understanding of the latter as an intermediary sphere wherein facts and values, means and ends, are necessarily entangled because expertise is crucial to the production of legitimacy in liberal-democratic societies. The paper concludes by asking what is the responsibility of the scientist as trans-scientist or expert and what institutions would best embody and support this vocation.
\end{abstract}

\title{
Keywords
}

expertise, trans-science, regulatory science, legitimacy

The title of this article - "Trans-science as a Vocation" - refers to a short text from 1972, "Science and Trans-science," by Alvin Weinberg (1972a), Nuclear Physicist and then Director of the Oak Ridge National Laboratory. It was written in the context of increased public worries about the risks posed by science and technology (especially nuclear power) and reforms (the 1969 National Environmental Policy Act in the United States) seeking to increase citizens' participation in decision-making about technical matters of public import. I am going to use Weinberg's text to address the question whether Max Weber's (1946 [1918]) argument in "Science as a Vocation" remains useful and valuable after a century, which saw extraordinary transformations and conflicts involving science. While the choice to compare Weber with Weinberg may seem quixotic - separated by more than a half-century, one was a sociologist speaking mostly to other social scientists about the need to leave political ideologies outside the lecture hall; the other was a

\section{Corresponding author:}

Gil Eyal, Department of Sociology, Columbia University, New York, NY I0027, USA.

Email: ge2027@columbia.edu 
physicist speaking mostly to other natural scientists about the need to admit the limits of their knowledge - there are good grounds for it. As we shall see shortly, there is no doubt that Weinberg was familiar with Weber's argument. He repeats it at the outset in order to indicate that it does not address the problems he will be discussing. Both authors, moreover, use strikingly similar formulations - speaking of "questions that are unanswerable by science" - to motivate their discussion. Most importantly, the two texts are comparable as blueprints for "boundary-work" (Gieryn, 1983), namely, for how and where the boundary between science and politics could be drawn and how scientists should conduct themselves as they inevitably cross it.

Let me rehearse quickly Weber's position, as I see it. Weber's lecture is justifiably famous for drawing a strict line between what science can and cannot do; between what should and should not be asked of science. This comes through the memorable quotation from Tolstoy: "science is meaningless because it gives no answer to our question, the only question important for us: "what shall we do and how shall we live?" (Weber, 1946 [1918]: 143). Scientists, said Weber (1949 [1904]: 54) in another programmatic text, cannot tell "anyone what he should do - but rather what he can do - and under certain circumstances - what he wishes to do." They can talk about facts, means, what is possible. They can compare different avenues of action in terms of feasibility, and in terms of entailed and unplanned consequences, clearly exposing the costs and advantages of different courses of action. Thereby they can even "indirectly criticize the setting of the end itself as practically ... meaningless with reference to existing conditions." Finally, empirical cultural scientists can also "offer the person, who makes a choice, insight into the significance of the desired object ... through making explicit and developing in a logically consistent manner the 'ideas' which actually do or which can underlie the concrete end" (Weber, 1949 [1904]: 53-54). In this way, they submit value-judgments to critical analysis of their internal consistency, assisting the actors to gain self-clarification. What they cannot do, however, is to scientifically plead "for practical and interested stands-except in discussing the means for a firmly given and presupposed end" (Weber, 1946 [1918]: 147). While the social scientist has a very important role to play in the field of social and economic policy; while she can provide many answers to questions about means, feasibility, comparative costs, and even internal consistency of the ends sought; she cannot derive policy choices from scientific research because this "involves will and conscience, not empirical knowledge" (Weber, 1949 [1904]: 54). Ends, values, meanings, are extra-scientific in a very strong sense. Weber's discussion was, therefore, geared toward identifying the imperceptibly thin and yet strict boundary, the "hair-line which separates science from faith" (Weber, 1949 [1904]: 110). Weber did not tell scientists never to cross this line. He did not equate objectivity with "neutrality," seeking a middle course, abstinence from value choice or with "moral indifference." Scientists should and must make value choices, but they should also make crystal clear "at which point the scientific investigator becomes silent and the evaluating and acting person begins to speak" (Weber, 1949 [1904]: 60). In other words, when they do cross the line, scientists must do so fully conscious of the fact and with "full disclosure," so to speak. This is a simple, perhaps simplistic, rendition of Weber's position. I think Weber's position, as it develops in the lecture, actually ends up being more complicated, and it is not without contradictions or tensions, but I will get to this later. 
Compare this with Weinberg's (1972a: 209) description of "trans-science" as "questions which can be asked of science and yet which cannot be answered by science." It sounds deceptively similar to Weber, drawing the same line, but it is not. In fact, Weinberg starts by repeating Weber's point almost word-for-word: "the scientist and science provide the means; the politician and politics decide the ends." He also seems to be familiar with the difficulties and subtleties critics have pointed out in Weber's argument. He echoes John Dewey (1922: 3-51) when he points out that drawing the line in this manner is "oversimplified" because

ends and means are hardly separable. What is thought to be a social or political end turns out to have numerous repercussions, the analysis of which must fall into the legitimate jurisdiction of the scientist, and each of these repercussions must be assessed also in moral and political terms; or what is thought to be a scientific means has non-scientific implications which also must be assessed in these terms.

While these considerations indicate that the "relationship between the scientist and the politician is ... more complicated," Weinberg notes that this is not his topic. He wants to talk about "a somewhat different aspect of the relation between scientific knowledge and decisions about social questions" (Weinberg, 1972a: 209). The key is in the "can be asked" part of the sentence quoted earlier. Weinberg's examples of "trans-scientific" questions include things such as the biological effects of low-level radiation insults, or the probability of "extremely improbable events" such as nuclear reactor accidents (written long before Chernobyl and Fukushima). The reasons why they cannot be answered by science are not because in principle they shouldn't be asked, because they are somehow questions about values and not facts. No. They cannot be answered because, as a practical matter, one cannot calculate them. One simply cannot build a thousand nuclear reactors and wait 10,000 years to compile the data necessary to estimate with some degree of confidence the probability of an accident. To estimate, at 95 per cent confidence level, whether low-level radiation causes cancer, Weinberg says, you'd need eight billion mice! Trans-scientific questions are, therefore, questions that "arise in the course of the interaction between science or technology and society." They are "epistemologically speaking, questions of fact and can be stated in the language of science," but "they are unanswerable by science; they transcend science" (Weinberg, 1972a: 209-211). It is true that Weinberg's somewhat unsystematic enumeration of trans-scientific questions proceeds then to include also what he calls "axiology of science" - namely, value-judgments internal to science such as criteria for scientific choice - regarding which he echoes Weber again:

in so far as value judgements - that is, ultimate questions of why rather than proximate questions of what - can never be answered within the same universe of discourse as the one in which the question arose, any resolution of these issues clearly transcends science even though the issues themselves seem to be internal to science. (Weinberg, 1972a: 213)

I feel justified, however, in setting aside this aspect of Weinberg's argument as irrelevant to the present discussion. It is telling, for example, that the much shorter rendition of his 
argument that Weinberg published in Science the same year contains no reference to this "axiology of science." It concentrates solely on the "problems that are beyond the proficiency of science to answer," namely, the examples of low-level radiation insults or estimates of extremely unlikely events (Weinberg, 1972b: 211). Clearly, Weinberg and the editors of Science recognized that herein lay the novelty of the problem he diagnosed. So the contrast I draw between Weber and Weinberg is perhaps somewhat accentuated and stylized, but this should be no objection. Weber (1949 [1904]: 90) himself has emphasized that the scientific method requires constructing and comparing "ideal types" that involve "analytical accentuation of certain elements of reality."

In what follows, I begin by drawing a deliberately accentuated contrast between "trans-science" and Weber's rendition of the boundary between the scientific discussion of means and the extra-scientific discussion of ends. I then ask what reasons Weber gives to defend his claim that the two should be separated. I contrast the empirical reasons Weber cites with an alternative account of the growth of "trans-science" or "expertise" over the last century, as an intermediary sphere wherein the two - facts and values, means and ends - are necessarily entangled because this sphere is crucial to the production of legitimacy in liberal-democratic societies. I conclude by asking what is the responsibility of the scientist as trans-scientist or expert and what institutions would best embody and support this vocation.

\section{What is trans-science?}

"Trans-scientific," therefore, means something different from Weber's "extra-scientific," a different blueprint for boundary-work. It is not an exceedingly thin "hair-line," but a thick intermediate zone between science and its exterior. On one hand, like science, it is composed of questions that can be asked of scientists. In fact, Weinberg's somewhat noncommittal "can" should be read as "will." These are questions that will be asked of scientists, inescapably so. They should and must be asked of scientists. There is no other way to deal with them but to ask scientists, even though, as Weinberg says, they "cannot be answered by science." On the other hand, like Weber's "extra-scientific," these are questions about how to act - should we allow low-level radiation or not? Or how much is low enough? Should we build more reactors or not? Should we add costlier safety features? The trans-scientific is clearly an intermediate space or an interface between science and its exterior. It consists of questions that, paradoxically, should and will be asked of science, even though scientists cannot answer them.

Weinberg's definition of trans-science is thus eerily similar to Niklas Luhmann's cynical quip that "an expert is a specialist to whom one can put questions that he is unable to answer" (quoted in Bechmann, 2003: 23). Once again the "can" in this sentence should be read as "will" and "should." Experts, whether scientific or not, may or may not be able to answer the questions put to them, but the recourse to expertise is the only legitimate way - in democratic societies - to address risk - whether "extremely improbable" or routine; whether posed by natural catastrophe, man-made pollution, economic processes, or terrorism (Ezrahi, 1990).

What exactly do Weinberg and Luhmann mean when they say that scientists and experts cannot answer these questions? After all, they do answer them, often, with 
obvious self-importance and little compunction. The main point is that to answer these questions requires making decisions on the basis of incomplete data, in conditions of high uncertainty, therefore resorting to this ineffable thing called "expert judgment." This is clear from Weinberg's discussion. He includes the whole field of engineering as trans-scientific because engineering projects, as a practical matter, require making decisions on the basis of incomplete data, and rely, therefore, on "engineering judgement": "this ability, as well as necessity to come to good decisions with whatever scientific data are at hand" (Weinberg, 1972a: 211-212).

If this formulation sounds familiar to social scientists, it is because it is almost identical to Bayes' Theorem. Bayes' Theorem treats probability not as objective distribution in a given population, but as subjective degree of belief. It describes how to update the degree of confidence attached to a subjective belief in light of new evidence. It is a way, therefore, of combining judgment (including prior assumptions common among a community of experts - known as "priors") with whatever incomplete evidence is at hand - hence its great utility and original use in code-breaking (Bertsch McGrayne, 2011). Trans-science is composed, in part, of expert judgment, and in another part of all the methods that have been devised to discipline and support expert judgment and to shield it from criticism - Bayesian statistics is the foremost and the most honest about the dodginess of the whole business, but one should include also operations research, decision theory, risk analysis, global circulation models, simulations, scenario analysis, resilience analysis and preparedness, stress testing, adverse events surveillance and monitoring, military intelligence assessment, the list could be extended. These methods are the bread-and-butter of trans-science. At the end of the day, however, they overcome the incompleteness of the data by means of all those things that, as Weber explained, are value-relevant and involve choice between values - presuppositions, assumptions, "priors," heuristics, conventions, "acceptable levels," cutoffs, and so on. It is easy to demonstrate, as Ulrich Beck (1992: 64-69) did, that these are chockfull of implicit values. In that, though in little else, Beck was being a good Weberian, charging that scientists failed to observe the "point" at which they, as scientists, should have "become silent," or more precisely, should have indicated that they were now speaking as an "evaluating and acting person" (Weber, 1949 [1904]: 60). The more important point, however, is that these methods are designed to answer - in a manner of speaking, using the rhetorical device of probability - precisely the question which Weber (1946 [1918]: 143), quoting Tolstoy, said science does not answer and should not be asked: "what shall we do and how shall we live?"

\section{Why, according to Weber, should facts and values be kept separate?}

Are they, therefore, illegitimate? These methods of trans-science seem to transgress the Weberian boundary between science and faith, facts and values, means and ends. To answer this question, we must ask first what reasons does Weber cite to defend his claim that these two should be separated, that these are questions that science cannot answer and therefore should not be asked? Here we get to Weber's famously agonistic conception of values. Values, inherently, are partial, one-sided, because to create significance 
out of the "meaningless infinity of the world process" inevitably entails selecting from it. Moreover, "the highest ideals, which move us most forcefully, are always formed only in the struggle with other ideals which are just as sacred to others as ours are to us" (Weber, 1949 [1904]: 76-81). To decide on a particular course of action, therefore, involves explicitly or implicitly choosing between ultimately incompatible values. This could be read as a universal, trans-historical claim about the nature of human knowledge, but in the same breath Weber (1949 [1904]: 57) also says that it is

the fate of an epoch which has eaten of the tree of knowledge ... that it must know that we cannot learn the meaning of the world from the results of its analysis, be it ever so perfect; it must rather be in a position to create this meaning itself.

The extra-scientific status of values and ends, therefore, ultimately rests on the thesis of disenchantment: "scientific pleading is meaningless in principle because the various value spheres of the world stand in irreconcilable conflict with each other" (Weber, 1946 [1918]: 147). The prohibition on confusing "is" with "ought" would have been meaningless for Leibnitz, even for Newton. As long as empirical investigations were seamlessly connected with metaphysical speculation in "natural philosophy," indeed even with political and religious thought as they clearly were in the famous controversy over the air-pump (Schaffer and Shapin, 1985), the spheres were not bounded from one another and, consequently, the strict boundary between facts and values would not have been intelligible (or useful) to contemporaries. ${ }^{1}$

There is a curious problem with this argument. It seems to violate the very boundary it was supposed to uphold. Indeed, this argument would seem to stand in such a stark self-contradiction, it is highly unlikely that Weber himself did not notice it. Essentially, by making this argument, Weber was violating his own dictum. He was deriving an ought - "Thou shalt not apply the values of one sphere to another!" - from a fact - "the spheres are really and truly differentiated from one another to such a degree that they are incompatible." Strictly speaking, Weber does not say that you shouldn't do this, only that you cannot do this, so he seems to be upholding his own covenant, but the ad hominem insults he levels twice at the "big children who are indeed found in the natural sciences" and the "few big children in University Chairs" betray his sense that he is on shaky ground (Weber, 1946 [1918]: 142-143). After all, the "big children" can and are doing this. They are claiming that their findings are telling us something about the meaning of the world. They move freely from science to religion and back. A no lesser figure than Francis Collins, who led the Human Genome Project, should be counted among these big children, since he wrote a book titled The Language of God: A Scientist Presents Evidence for Belief (Collins, 2006). The very metaphor of DNA as "the book of life" gestures at profoundly religious themes. I am going to leave this problem aside for the moment, and return to it at the very end of the article.

\section{Expertise as an intermediary between science and politics}

So, to give a very preliminary answer to the question with which I started, it doesn't seem to me that Weber's argument is as useful or as relevant now as when it was first 
formulated. His argument that science and politics are two radically separate value spheres between which there is a fine ("hair-line") and yet sharply drawn boundary is thoroughly refuted by the experiences of the last 100 years. During the century that has passed, a vast middle sphere has opened up between them, an interface or a bridge that at one and the same time separates and connects them. Weinberg calls it "trans-science," but you can also call it "regulatory science" (Jasanoff, 1990, 1995) or even more simply and generally "expertise." We have become used to thinking and talking about "expertise," but the reality is that this word has entered wide circulation only in the 1960 s, just a little bit before Weinberg coined "trans-science." This was no accident. It was a response to the growth of regulatory science, this interface between science and politics, and to the debates, struggles, and controversies around it. These controversies necessitated a new word, and "expertise" was summoned to do the job. The increased recourse to this word, "expertise," reflects not the rise of post-industrial "knowledge society" (Bohme and Stehr, 1986; Stehr, 1994) but its crisis, the worsening friction and contestations at the intermediate zone between politics and science. ${ }^{2}$

Let me use the analogy of a three-lane highway to explain what I mean and why it may require updating Weber. The left, fast lane, belongs to politics, law, and policy. It is a fast lane - however much we may complain that "the wheels of justice turn slowly" because law and politics need to arrive at a decision about how to act. The right, slow lane, belongs to pure scientific research (of various kinds). It is slow not simply because it takes the long view, but fundamentally because it does not need to make a decision about how to act. Instead, scientific research is carried within a peculiar temporal frame, a sort of "reversible time" (Levi-Strauss, 1963). There is no clear end point marking an established present as against a consummated past. One can always, at least in principle, roll time back and run the experiment again, modifying another element (at least until the grant runs out). Put differently, pure scientific research delivers facts that are open-forward, so to speak, constantly revisable, while legal or policy decisions deliver facts that are closed. They cannot be revised (even if they are manifestly wrong) - unless the whole cumbersome process of collective decision-making is set in motion again - because they serve as the basis for action and because one needs to preserve the fragile stability of the whole framework of which they are but one node (Latour, 2010). The middle lane, finally, where the fast and the slow must adjust to one another (horns blaring, curses muttered under breath), belongs to regulatory science, trans-science, policy science, expertise. While the methods used in regulatory science may seem superficially similar to the methods used in pure research, they operate within a distinct temporal frame. To bridge open-forward scientific facts with closed, actionable legal and policy facts, regulatory facts take the distinctively temporal format of cutoffs, thresholds, guidelines, surrogate end points, acceptable risk levels, consensus documents, expert assessments, simulations, stress tests. These can become nearly immutable, etched in regulations and backed by legal sanctions, yet they are also inherently provisional and convention-like. By their very nature, as the site where open-ended inquiry and decision-making need to be reconciled, they are contentious and crisis-prone.

Were Weber's activities in the Verein für Socialpolitik or as editor of the Archiv für Sozialwissenschaft part of the middle lane? I do not believe so. Weber and his colleagues were indeed acting or offering themselves as "policy experts" of sorts. They 
wrote reports on the labor question, factory legislation, the conditions of factory workers, the plight of agricultural laborers, and so on. As editor, Weber (1949 [1904]: 60 ) is emphatic that analysis of social policy, criticism of its premises, proposal of alternatives, even debate between opposing political perspectives and value-judgments, were all publishable as legitimate contributions, as long as the scholar clarified the standards from which the value-judgment derived, and indicated the point at which the scientific analysis ended and the value-judgment began. This formulation, however, is telling. There is no middle lane! It is as if the scholar is forced to swerve from the slow lane to the fast in the blink of an eye (and pray that an accident can be avoided!). Put differently, what is missing from Weber's formulation is the distinctive temporal frame of regulatory or trans-science and the institutions that support it. The scientist or the scholar is left to her own devices, without institutional resources or sanctions, to manage the transition between "is" and "ought." Indeed, she must embody the tension between them, must advertise that she knows when and how to switch "hats," even though this is probably an impossible task. As Weinberg (1972a: 209) said, what is considered merely "means" at one time, can be disclosed in the next round as having non-scientific implications and as requiring discussion in moral and political terms.

\section{The production of legitimacy}

This peculiar, tortured temporality of regulatory facts is because what they are designed to do is to produce legitimacy. Here, in fact, Weber is extremely useful, though also in need of updating. Weber's peculiar, unsentimental approach to systems of government - including contemporary liberal, "illiberal," corporatist, and statist democracies, in each of which expertise is organized somewhat differently (Campbell and Pedersen, 2014) was to treat them as "techniques, like any other machinery" (quoted in Mommsen, 1984: 396; see also Eliaeson, 2000). By this he meant that the most important thing about them is not whether they are just or not (legitimacy is not justice), but whether they work in the sense that most of the time, most of the people, obey most of the commands, without too much friction gumming up the works. Obedience is a probabilistic, aggregate, machine output, measured by its efficiency, namely, whether commands are obeyed and competent people are selected for leading roles. Whenever the machine is working well, says Weber (1978: 212-215), whenever most commands are obeyed by most people most of the time, this is evidence for the presence of an extra ingredient, over and above all the other motives for obedience, namely, "belief in legitimacy ... which every such system attempts to establish and to cultivate."

Yet, Weber (1978: 214) immediately cautions against treating this belief in legitimacy purely psychologically: "it is by no means true that every case of submissiveness to persons in positions of power is primarily (or even at all) oriented to this belief." So what is this "belief in legitimacy?" This extra ingredient that is absolutely essential, yet never truly present? Weber leaves us dangling but adds a crucial parting shot: whatever motives play a role in any individual act of obedience, they are "not decisive ... What is important is the fact that in a given case the particular claim to legitimacy is to a significant degree and according to its type treated as "valid." So everything hangs on how we 
understand what is meant by "valid." My suggestion is that we think of validity as defensibility and that we keep this term intentionally ambiguous, gesturing as it does in one direction to strength, fortification, and struggle - etymologically, the Latin validus means "strong, effective," the verb valere is "to be strong" - and in the other direction to reason, argumentation, and discourse; the ambiguity summed up in the expression "force of the better argument." Validity - hence legitimacy - is a well-woven web of arguments, procedures, measurements, and institutions, all supporting one another, so they are wellfortified, defensible. ${ }^{3}$

While Weber's "types" of legitimate domination seem to suggest that this web has a center, a core or a fount from which legitimacy flows, I prefer to think of it as a centerless maze. The defensibility of commands is similar to leading the commanded into a labyrinth, where all the road signs point toward the conclusion at which they "should" arrive, and all the other turns lead into blind allies, gates guarded by fearsome doorkeepers, long corridors where all the doors are closed, and interminable waiting rooms. Having tried their hand at some of these confrontations; exhausted themselves in some of these runarounds; wasted time in the cul-de-sacs; having tried "enough" times; the rank-and-file ultimately follow the signposts and arrive at the appointed exit acknowledging that the conclusion is "valid." The maze has no center. There is no Ur-source in which the capacity to persuade is stored. There are only walls and the cunning intelligence that built them. Getting people to follow commands depends on an art of persuasion, namely, rhetoric (Ezrahi, 1990; Friedrich, 1972), understood in the broadest possible terms to include not only reasoned argumentation but also institutional and spatial arrangements, instrumentation, quantitative measurements, tests, and demonstrations. ${ }^{4}$

Clearly, the experiments, measurements, procedures, protocols, and standards that produce regulatory facts play a crucial role in the orchestration of defensibility and persuasion. They are rhetorical through and through. The time of defensibility is neither the breathless, irreversible time of a decision, nor is it (passé Habermas) the theoricist, reversible time of endless discussion. It is a time of finite repetition, of repeated tests (in both the scientific and legal sense) and counter-tests (repeated attempts to get out of the maze in other directions) until the clock runs out. Legitimacy depends on crafting temporal frames that foreground discussion, indeed ceremonialize the time it takes; yet are also geared toward bringing controversy, debate, search, research, to a provisional end, while also offering a glimpse into an horizon where they may be continued ("we can pick it up again next time"), even as legitimate decision and action can now take place. While there are important cross-national differences in how expertise is organized to produce legitimacy, especially in terms of how competitive or coordinated is the organizational field of knowledge production, how central is the role of the state, and whether an adversarial or negotiated process is privileged (Campbell and Pedersen, 2014; Turner, 2014: 9, 12-13, 114-137), all such arrangements nonetheless face the same need to organize defensibility and frame its temporal horizon. This is what a lot of science - trans, regulatory - is about these days, this is what expertise is about. This is also why the scientists and experts are constantly asked these questions that they cannot (truly, definitely) answer - because they participate in the production of legitimacy. 


\section{Trans-science as a vocation}

What is the responsibility of scientists as experts and trans-scientists, who participate in the production of legitimacy? Weinberg's (1972b: 211) answer was ultimately Weberian:

What the scientist can do in clarifying matters of trans-science differs from what he can do in clarifying matters of science. In the latter case, he can bring to bear his scientific expertise to help establish scientific truth; in the former case, he can, at most, help delineate where science ends and trans-science begins. We scientists sometimes refuse to concede that science has limits. The debate on risks versus benefits would be more fruitful if we recognized these limits.

This is almost exactly the same as Weber's (1949 [1904]: 60) demand that the scientist make clear "at which point the scientific investigator becomes silent and the evaluating and acting person begins to speak." It is the same blueprint for boundary-work. The job of scientists is to identify for decision-makers what can and cannot be answered by science, to draw a line, and then leave trans-scientific matters for public deliberation. If they want to participate in this deliberation, they must take off their expert hat, step outside the lecture hall, and do so as ordinary citizens.

The preceding discussion should make it clear that this answer is inadequate. To put it very simply at the outset, if trans-science is this intermediate region between science and politics, then the Weberian answer provides no guidance for how the expert should behave inside this region. Moreover, if trans-science is about the institutionalized production of legitimacy, to limit the expert's role to merely indicating where science must hold its tongue would be irresponsible, nor does it provide a good description of what happens in this intermediate region. Put more theoretically, this answer fails as a blueprint for boundary work. It has always struck me as a peculiar omission in the concept of "boundary work" that nobody asks where boundary work itself takes place. Boundary work is political work, so it is not conducted on the "science" side of the boundary. It is something that scientists do in op-eds and press conferences, not in laboratories. But it is also work done so scientists can stay on the science side and so it is also not quite on the "political" side as well. One cannot escape the answer that boundary work is conducted within the volume of the boundary itself, which is to say it transgresses the boundary even as it draws it (Eyal, 2006: 7-8; Foucault, 1998; Latour, 1993; Mitchell, 1991). It follows that the act of "conceding that science has limits" is itself part of transscience. Arguing about where lie the limits of what scientists can say with confidence is trans-scientific through and through, and it is not clear that the Weberian stricture provides us with any guidance on how to conduct this debate. Perhaps a more straightforward way of expressing this objection is to say that the argument is not about what scientists can say with confidence, but about what they should say without confidence. If there are risks, there is no question in the matter. Our duty is to prevent them. If there are no risks, similarly there is no question in the matter. But trans-science is about uncertainty, about "acting in an uncertain world" (Callon et al., 2009), about when are precautionary measures justified even if we cannot be confident in our detection and assessment of a correlation or a causal link. To give a contemporary, urgent example, pointing out the limits of science, pointing out the uncertainties that render a question "trans-scientific," this has become a favorite strategy of stalling deployed by the 
"merchants of doubt," whether they are working for big tobacco, or have independently come to the conclusion that there is no conclusive proof of man-made climate change, or are spooked by what they perceive are the perils of vaccines (Conway and Oreskes, 2010; Proctor and Schiebinger, 2008). Too often now, to do "one's damned duty," as Weber would have said, means to resist this strategy, which paradoxically should mean to insist that the trans-scientist can and should speak about these questions as an expert, even though she cannot answer them conclusively, even though she has to admit the uncertainties; she must nonetheless add the weight of her instruments, evidence, and judgment to unbalance the scales.

Weinberg (1972a: 220) admits this. He says that the border between science and transscience is inherently "elusive," and that consequently "trans-scientific debate ... inevitably weaves back and forth across the boundary between what is and what is not known and knowable." In this context, to concede that science has limits and to leave it at that is irresponsible. By the same token, however, to refuse to admit the limits of scientific knowledge is disingenuous and ultimately discrediting. As Weber (1946 [1918]: 146) says, "the device of 'letting the facts speak for themselves' is the most unfair way of putting over a political position to the student." Weinberg (1972a: 216; 1972b: 211) concurs. Scientists should be candid about "the limits to the proficiency of their science," or they will lose their credibility with the public. Yet if they are candid about the uncertainties, aren't they likely to increase public mistrust and play to the hands of the "merchants of doubts"? It is clear that the Weberian blueprint for boundary work has failed. Boundary work can no longer be imagined as an individual act of ascetic restraint. We need a different image.

Indeed, Weber's attempt at boundary work has been criticized as "decisionistic" because it assumes that ends and means could be clearly separated, and it seems to envision a linear institutional sequence in which politicians define the problems, scientists provide technical advice, and then politicians once again make a decision, taking the advice into account (Weingart, 2003: 60-62). In reality, none of the steps in this model provides a convincing account of, or prescription for, contemporary relations between science and politics. First, regarding problem definition, many of the problems at the top of the contemporary political agenda have been placed there by scientists and experts (e.g. climate change, or more generally "risk"), rather than by politicians or the public (Weingart, 2003: 62-64). Even if they formally appear to have been posed by the politicians, in reality they are defined in a recursive back-and-forth between scientists and politicians. In the Dutch case, for example, the Ministry of Health supposedly formulates the problems and then consults the Gezondheidsraad, the Health Council. In reality, however, the Gezondheidsraad's staff meets regularly with the Ministry's officials, prior to the moment when the official question is posed, to work out together the definition of problems and the wording of the questions, so as to prevent tensions, misunderstandings, and the public airing of controversies (Bijker et al., 2009: 47-55). The formal process, therefore, is primarily a framing device, almost a ritual, geared to generate legitimacy by seemingly separating in time and space the moments of question and answer, decision and consultation, fact-finding and choice between values. Inevitably, however, it gives rise to a thickened boundary, an intermediate zone wherein the negotiation takes place. A new problem now emerges, more properly trans-scientific: Should these negotiations be shielded from public view? Who should have access to them? On what basis could access 
or transparency be denied? If they are fully open and transparent wouldn't they devolve into chaos or diminish public trust in regulatory science?

Second, regarding scientific advice itself, the more it takes the form of what I called "regulatory facts" (cutoffs, thresholds, acceptable risk levels, expert assessments, etc.), the less it becomes possible to clearly distinguish between facts and values, means and ends (Beck, 1992: 64-69; Weingart, 2003: 64-69).

Finally, regarding political decision-making, it is not the case that politicians are free to decide as they will once authoritative expert advice has been officially rendered. As Friedrich (1972: 47) says about the etymology of "authority," this is the sort of "advice which cannot be safely disregarded." Indeed, the need to follow such advice is often baked into the legal tests for the legitimacy of administrative action (Ezrahi, 1990; Jasanoff, 1989).

The image of a razor-thin boundary between science and politics is replaced, therefore, with a different one, namely a "recursive coupling" between science and politics (Weingart, 2003: 70), this "weaving back and forth" foreseen by Weinberg (1972a: 220), and exemplified by the informal negotiations conducted by the staff of the Gezondheidsraad. The question of the responsibility or vocation of scientists as transscientists, that is, as experts, is about how they should behave inside this intermediate zone. It therefore becomes intimately linked to a question of institutional design: what should the "republic of trans-science," so to speak, look like?

\section{The republic of trans-science}

Weinberg (1972a: 214-216, 220) thought that "in trans-scientific debate ... confrontation between scientists of opposing ethical or political positions is desirable." Weber would likely have agreed, given his conviction that conflict and struggle were an intrinsic element of social life. ${ }^{5}$ On the whole, Weinberg trusted in the adversary process to sort out trans-scientific questions and to force scientists "to be more honest, to say where science ends and trans-science begins, as well as to help weigh the ethical issues which underlie whatever choices the society makes between technological alternatives." The partisanship permitted to the expert witness within the adversary process, he seemed to say, could be an acceptable model for the vocation of the transscientist. He had some lingering concerns, however, since the adversary procedure is not particularly good at establishing who has the relevant expertise to be such a witness. Consequently, trans-scientific debate may become unruly. If scientists join the adversary fray and do not exercise "the cannons of scientific discipline ... What do they have to offer that the next man doesn't? If all questions are political, why not leave them all to the politicians?" (Weinberg, 1972a: 220). In marked contradiction to his apparent trust in the adversary process, he urged scientists that their role must be to contribute to the "development of better institutions for conducting trans-scientific debates" (Weinberg, 1972b: 211).

Weinberg's final musings on the subject indicate that he was worried most of all about the feedback effects that broad participation by the public in trans-scientific debate (which he nonetheless thought inevitable and ultimately desirable, compared with the alternative) might have upon science itself. This feedback effect across the boundary is another sign that the Weberian blueprint for boundary work no longer 
applies to trans-science. Yet, his discomfort about modeling trans-science on the institutionalization of partisanship characteristic of Anglo-American law - and now also of intellectual life in the form of the field of think-tanks (Medvetz, 2012) - betrayed his sense that there is an even more fundamental difficulty. After all, science was called upon to assist the court where judicial authority faltered. How could it rely upon this same authority to resolve its own internal struggles? The tumultuous history of scientific expert witnessing - another type of "recursive coupling" - documents the instability of this arrangement (Golan, 2004). The institutionalization of partisanship can work as a mechanism for producing legitimacy only if the battle is joined before an authority (judge and jury) that is able to ratify the result. As Mary Douglas (1990) says,

There has to be a Solomon to judge; the evidence does not provide the judgment by itself. In the present circumstances the appeal to science is made because of the absence of respect for any adjudicator. Solomon's role is not acceptable.

With Solomon absent, modeling trans-science upon institutionalized partisanship is a recipe for polarization, discord, and paralysis.

The Weberian blueprint was based, as I've argued, on a diagnosis of the historical moment in which it was formulated. Similarly, the question of trans-science is raised in response to the palpable sense that the mechanisms that produce legitimacy in Western democracies, whether of the liberal, corporatist, or statist type, are undergoing a prolonged crisis. As science was called upon to play an increasingly central role in orchestrating the legitimacy of democratic states, it has become itself polluted and is increasingly losing the ability to do so. As Peter Weingart (2003: 56-57) put it in a succinct formula, the "scientization of politics" has led to the "politicization of science." There are currently four responses to this problem, four institutional models for the republic of trans-science and for the vocation of the expert. None of these responses is satisfactory. They all suffer from distinctive weaknesses. Moreover, while they constitute a series in which each responds to the vulnerabilities of its successor, they also co-exist and interact, thereby undermining one another. Although there are important differences between democratic states regarding which response tends to predominate (Campbell and Pedersen, 2014), none has managed to establish a working model for the republic of trans-science. The resulting unstable mixtures, rather than arresting the crisis of legitimacy, seem to be lending it momentum. The crisis, in fact, is no longer distinct from the institutions and strategies of crisis management.

Weingart (2003: 79-81) characterizes the first response as the creation of artificial scarcity of expertise. This is an exclusionary response exemplified by national scientific councils like the Gezondheidsraad (Bijker et al., 2009), as well as science courts (Decoteau and Underman, 2015), advisory committees (O'Kelly, 1989), scientific boards, consensus panels, and lists of certified experts kept by state regulatory agencies (Carpenter, 2010). It is more typical of continental corporatist democracies, where the emphasis is on coordination and negotiation, but it is also characteristic of US agencies such as the Food and Drug Administration (FDA) or the Environmental Protection Agency (EPA). It can be construed as a negation or a taming of the 
adversary process. Where institutionalized partisanship faltered, unable to tell who has relevant expertise, who should participate in trans-scientific debate, the state takes over and endeavors to organize scientific consensus by various gate-keeping mechanisms that limit who can participate in the recursive back-and-forth, and shield it from outside scrutiny. The vocation of the expert is to exercise expert judgment in accordance with the professional ethos, studied neutrality and commitment to the public weal characteristic of a strong civil service (Breyer, 1993). The obvious weakness of this strategy is that the very procedures meant to select the experts, communicate their neutrality, and shield their consultations can appear as stacking the deck; as being nontransparent, cutting off debate prematurely and thus leading to widespread skepticism and suspicion (Jasanoff, 2002).

The obverse, diametrically opposite, strategy is for the government and regulatory science agencies to involve lay members of the public in the deliberations of expert advisory bodies. This is an inclusionary response exemplified by the public hearings required for an environmental impact assessment in the United States (Rowan, 1994: 397-398), the French "citizens' conferences" (Callon et al., 2009: 169-176), the transparency measures taken by the UK Food Standards Agency after the "Mad Cow" crisis (Jasanoff, 2003: 236-237), and by the mandatory inclusion of patients or patients' advocates in the deliberations of advisory bodies, the design of clinical trials, and the drug approval process (Abraham and Davis, 2011; Carpenter, 2010; Epstein, 1995; Prior, 2003: 396-398). Formal participatory measures are better institutionalized in liberal democracies such as the United States and United Kingdom, but they are increasingly de rigueur everywhere. The state endeavors to cleanse regulatory science from the taint of political or industry bias caused by gate-keeping and opacity, by including "stakeholders" - ordinary citizens, advocacy and watchdog groups, businesses, and so on - in deliberations on matters directly relevant to them. The vocation of the expert is defined by the ideals of accountability, transparency, and responsiveness. I have my doubts. I have a strong Weberian gut reaction. These are attractive ethical ideals, but poor machineries for producing legitimacy. No commands are issued and nobody is obeying! The weaknesses of inclusion strategies are all too obvious. They are caught on the horns of a dilemma. Including members of the public in consultation and decision-making can generate short-term legitimacy, but it also reduces the ability to persuade and the likelihood of consensus, which damages legitimacy in the long-run. "Transparency may exacerbate rather than quell controversy ... Participation ... becomes an instrument to challenge scientific points on political grounds" (Jasanoff, 2003: 237). It increases "inclusion friction," a damaging slowdown of the knowledge production and policy formulation processes (Edwards, 2010: 421-427), while also neutralizing the authority of the experts, who are reduced to the role of facilitators (Rowan, 1994). This creates the distinct possibility that the process will be hijacked (as Weinberg worried long ago) by whoever is best able to present themselves as authentic representatives of citizens' interests.

Hence the increasing recourse to a third strategy, which seeks to reduce as much as possible reliance on both expert judgment and lay participation. This is a strategy of "mechanical objectivity" (Daston and Galison, 1992; Porter, 1995: 4-5). It aims to eliminate the element of human (expert or lay) judgment, error and bias, replacing it with strict - "mechanical" - adherence to formal, explicit, and transparent rules; quantitative 
measurement of performance, and standardized tests. This preference for "trust in numbers" is exemplified by the central role of randomized controlled trials (RCTs) in the drug approval process (Carpenter, 2010), and now also in domestic social policy and international development (Gueron and Rolston, 2013; Leao and Eyal, 2019), and by the demand for "measurable results" now characteristic of educational reforms (Bhatt, 2018). This response can be found in all democratic regime types, but especially in policy areas where the findings of regulatory science would effectively be picking "winners" and "losers" in the marketplace, as is true of the nearly trillion dollars' worth pharmaceutical industry. The enormous pressure for "fairness" leads experts to identify their vocation with neutrality and self-effacement:

One of my great assets of being in this business, or maybe I've developed it over time, is I don't have many opinions to start with [...] I have one opinion - one should evaluate things - which is strongly held. I'm never unhappy with the results. I haven't yet seen a result I didn't like.

(Esther Duflo, quoted in Parker, 2010)

It is a miraculous, improbable blend, therefore, of the populism of inclusionary strategies (thus negating exclusionary ones) with the technocratic emphasis of exclusionary strategies (thus negating inclusionary ones). The main weakness of this strategy is simply that it promises more than it can deliver (the blend, as I said, is improbable). There is voluminous literature by now documenting the limitations, failures, and biases of RCTs and standardized tests, the fact that they do not eliminate the need to rely on expert judgment, and the contentious politics to which they give rise (Carpenter, 2010: 387-390, 393-410, 476-492, 508-509; Cartwright and Deaton, 2016; Demortain, 2011: 53-57; Porter, 1995: 6-48).

The fourth and final response is less coherent. Coming after all three others, it is assembled from various reactions to their diverse shortcomings. Primarily, it is an "outsourcing" strategy whereby the conduct of regulatory science and the organization of scientific consensus is sub-contracted out and below, to interstitial entities that exist on the margins of the state (Demortain, 2011: 44-47, 53-59, 66-67). Clearly, this is a response to the vulnerabilities of gate-keeping arrangements, as well as to the perception that inclusionary policies are merely "window-dressing." Outsourcing arrangements often arise "from below." They assemble together diverse and complementary sources of expertise. Committed to transparency, they evolve ever more distributed forms of pooling and vetting expertise. Finally, in marked reaction to mechanical objectivity strategies, they seek to generate legitimacy by admitting and foregrounding uncertainty rather than certainty, experimentalism rather than decision, precaution rather than prevention, trained judgment rather than procedures (Callon et al., 2009: 191-223). The Intergovernmental Panel on Climate Change (IPCC) is perhaps the best example of this type of response to the crisis of legitimacy (Edwards, 2010: 398404), while Dewey's experimentalism captures best how it envisions the vocation of the trans-scientist - even who is the trans-scientist is a matter of experimental discovery in the "hybrid forums" composed of experts and laypeople (Callon et al., 2009: 153-190). Because this is a response to all the other responses, it also replicates their multiple weaknesses. Like institutionalized partisanship and inclusionary strategies, who has relevant expertise is left in 
flux. As demonstrated by the public controversy over the IPCC's reports and "Climategate" (Beck, 2012; Editorial, 2010), the attempt to organize outsourced scientific consensus leads to suspicion that the deck has been stacked. Most importantly, the embrace of uncertainty and experimentalism means that the outsourcing response possesses no reliable mechanism for bringing debate to an end, and no test to distinguish between reasonable and unreasonable doubt (John, 2018). Indeed, Callon et al. (2009: 16) deny that bringing debate to a provisional end is even a desirable goal. They see "no reason to halt" the "socio-technical spiral": "The only reasons for halting it are bad ones."

In consequence, there is not at the moment a viable model for the republic of transscience. The four responses not only have their weaknesses, but they undermine one another, thereby exacerbating the crisis of legitimacy. On one hand, once inclusionary strategies have been institutionalized, they become entrenched. It is impossible to return to the model of gate-keeping and opacity. Indeed, if we'd like people not to be astounded when the curtain is pulled back and they see how the scientific sausage gets made (as happened with Climategate), they need to be there, behind the curtain, much earlier and throughout the process. On the other hand, the inconvenient fact is that openness, inclusion, transparency, and participation do not, by themselves, secure legitimacy. Just as often, they undermine it. There is a point of high tension here, perhaps an antinomy: can there be rational recognition of an appeal to rational authority? Since the authority of rational commands is based on their "discursive redeemability," that is, on the supposition that they could, if necessary, be justified and defended against critique, is it permissible to say that right now, here, for this purpose, it is not necessary to produce the full defense; that instead it should be accepted on the authority of the expert? For the authority of the expert to be accepted, citizens need to be educated. Yet, once they are educated, they no longer accept "appeals to authority" and they demand to see the full proof.

This is a dispiriting conclusion, but it should not lead to paralysis. Bad news should be faced head on, as an impetus for rethinking and revising one's approach. This is probably the most enduring, moving, and relevant message of Weber's lecture. It is certainly the one that I have found the most useful in my own teaching and scholarship: "The primary task of a useful teacher is to teach his students to recognize inconvenient facts - I mean facts that are inconvenient for their party opinions" (Weber, 1946 [1918]: 147). Alvin Gouldner (1976) called this "bringing the bad news." A dangerous mission, by all accounts, as we know what the proverb says about the fate of messengers bearing ill-tidings. More dangerous still because it must apply to the teacher herself. You teach students (or the public) how to recognize inconvenient facts by recognizing them yourself, recognizing and grappling with precisely those facts that are inconvenient to your party opinion. Yet, as Weber says, if one manages to make even a small contribution toward developing in others the faculty of recognizing, acknowledging, even seeking out the inconvenient facts, then it may be reckoned as nothing less than a "moral achievement."

\section{Conclusion, or the enduring charisma of "Science as a Vocation"}

Herein, perhaps, lies the reason for Weber's seeming self-contradiction regarding disenchantment and his ad-hominem attacks on the "big children." Teaching others how to recognize or even seek out inconvenient facts is not something that can be done playfully, 
in a distanciated manner, as some military intelligence services do by assigning an officer or a unit the role of advocatus diaboli. It is something that can only be done ad hominem, demonstrated on one's body, so to speak, because it is about how to live an authentic, responsible, ethical life. Ultimately, Weber did not derive the vocation of science from the fact of disenchantment, but from a moral choice about how one should live with contradictions and inconvenient facts. That his choice was amor fati, or in other words, authenticity, is proven by the very ending of the lecture, where he contrasts his own willingness to "bear the fate of our times" - to bear and love it, that is (as Nietzsche would have said) - with the Jews, the people who - in this narrative - refuse the "fate of our times," who "has enquired and tarried for more than two millennia, and we are shaken when we realize its fate" (Weber, 1946 [1918]: 155-156). Strangely prophetic words.

Herein also lies the peculiar and enduring charisma of "Science as a Vocation," even after a century. "Charisma," in Weber, has multiple meanings, but perhaps the most insightful is as the capacity to embody and thereby reconcile contradictions, at least temporarily. This is suggested by the contradictory language with which Weber (1978: 242245) speaks about charisma and charismatic authority. On one hand, the authority of the charismatic leader is dependent on a proof (usually a miracle). He must prove that he is an extraordinary individual by performing extraordinary acts or by accurately prophesying the future. When charisma is "genuine," however, Weber says, its validity rests on the conception that it is followers" "duty" to obey it, which is basically the opposite of the need to provide proof. This is not a logical contradiction, or sloppiness, but the way in which Weber's "ideal type" methodology records a real tension. What Weber captures with this concept is a real conflict, which explains to us why Weber placed so much emphasis on charisma as the major revolutionary force in traditional societies. The charismatic leader embodies this tension, or conflict, and "resolves" it in a creative way, in a way which impresses the laity deeply and can lead to a trans-valuation of all values. What is this tension? As is well-known, for Weber (1991 [1922]), the history of religion is a struggle between different "suppliers of salvation," in particular between magicians, priests, and prophets, each seeking to establish a monopoly over the supply of salvation to the laity. A monopoly over the supply of salvation allows the religious expert to convert the laity from (sovereign) consumers to followers, over which she exercises domination, the power to issue legitimate commands. The whole point of this struggle is to establish such a monopoly over "proof" (salvation) so it could be converted into "duty" (domination); to control supply to such an extent as to be immune to the forces of demand. So "proof" expresses the dependence of religious actors on the laity; "duty" expresses their autonomy. Or said differently, the religious field is constituted by the opposition and tension between this-worldly and other-worldly salvation; and by the opposition and tension between traditional and charismatic domination (Bourdieu, 1987; Eyal, 2002). The truly charismatic leader embodies all these contradictions and reconciles them, at least for a moment - because charisma is really a property of situations rather than personalities and the main problem for the religious expert is how to make it permanent.

"Science as a Vocation" was one such charismatic situation, a fleeting charismatic moment. In the course of this lecture, Weber spoke as a scientist and as a prophet at one and the same time, offering in his own body - the deep set eyes, the furrowed brow, his manner, and his bearing - to reconcile the contradictions that he himself outlined so well, even if only for a fleeting moment. Think about what he said: one should charge forward, 
"obey the demon who holds the fibers of his very life," one should work in a calling and be a partisan for one's "ultimate values," and yet one should also stop on a dime, observe the hairline that separates science from faith. He created an immense tension between enormous energy and profound abstinence, outlining an antinomy that could not be resolved, only lived. Trans-science as a vocation would need a similar charismatic moment or a theater wherein the open curtain of inclusion and the authoritative voice of expertise are held together in dynamic tension.

\section{Declaration of conflicting interests}

The author(s) declared no potential conflicts of interest with respect to the research, authorship, and/or publication of this article.

\section{Funding}

The author(s) received no financial support for the research, authorship, and/or publication of this article.

\section{Notes}

1. In a spirited and highly critical review of a draft of this article, Steve Fuller objected vehemently to this passage. He thinks that I have seriously misstated Weber's position regarding the limits of science. The reason why science cannot tell the actor how to act is because this is objectively indeterminate (while the limits that Weinberg describes refer to merely "subjective ignorance") - it can never be otherwise. This objective indeterminacy of possible courses of action gives rise, therefore, to a sphere of freedom, which is where politics enters. It follows that Weber's position regarding the limits of science has nothing to do with the thesis of disenchantment. I cannot adequately address Fuller's serious criticism within the scope of this article. I will confine myself here to three points: (1) the textual evidence, the references to disenchantment and to "eating of the tree of knowledge," as well as Weber's (1946 [1915]) well-known analysis of the differentiation of the spheres would seem to support my interpretation; (2) if the actors do not believe that there are multiple equivalent perspectives - as the natural philosophers clearly did not - in what sense could we say that how to act was "objectively indeterminate" for them? (3) as a sociologist, I prefer to treat Weber and Weinberg symmetrically. Instead of qualifying the limits diagnosed by one as merely "subjective," while anointing the limits identified by the other as "objective," I deal with both as comparable blueprints for boundary-work between science and non-science.

2. To be convinced that "expertise" is really a very recent word, Google Books ngram viewer is extremely useful: https://books.google.com/ngrams/graph?content=expert\%2Cexpertis $\mathrm{e} \% 2 \mathrm{C}+$ professions\&year_start $=1800 \&$ year_end $=2000 \&$ corpus $=0 \&$ smoothing $=3 \&$ share $=\&$ direct_url=t1 $\% 3 \mathrm{~B} \% 2$ Cexpert $\% 3 \mathrm{~B} \% 2 \mathrm{Cc} 0 \% 3 \mathrm{~B} .11 \% 3 \mathrm{~B} \% 2 \mathrm{C}$ expertise $\% 3 \mathrm{~B} \% 2 \mathrm{Cc} 0 \% 3 \mathrm{~B}$ .t1\%3B\%2Cprofessions\%3B\%2Cc0 (last accessed 2 August 2018).

3. This discussion of Weber's sociology of domination is inspired by Ivan Szelenyi's lectures on the subject, which I was fortunate to attend. See also Szelenyi (2016). My characterization of legitimacy as defensibility draws inspiration from Habermas' (1973: 95-108) understanding of legitimacy as "discursive redeemability." At the same time, my approach differs from Habermas in that I draw on Bourdieu's (2000: 191-202; Wacquant, 1992) praxeological approach to treat the temporality of legitimacy practically, as an artful, skilled accomplishment.

4. This updating of Weber draws on Carl Friedrich's (1972: 48, 93) influential critique of the opposition between rationality and tradition that underpins Weber's distinction between traditional, rational-legal, and charismatic domination. Friedrich argues that Weber has conflated 
"authority" and "legitimacy." All systems of domination - the traditional and charismatic included - rely upon authority, namely, "the capacity to issue communications that can be elaborated by convincing reasons." All systems of domination perforce - the rational-legal one included - are supported by the "art of authoritative reasoning," namely, rhetoric. I fully agree. If I prefer, nonetheless, to speak only of "legitimacy" and avoid distinguishing it from "authority," this is because, first, my reworking of legitimacy as "defensibility" essentially rebuilds it on the model of an "art of authoritative reasoning" and, second, because from the point of view of centerless defensibility there is a seamless transition (and often entanglement) from defending a command in terms of the correct political procedures of representation to defending it in terms of the correct scientific procedures of demonstration (Ezrahi, 1990).

5. My thanks to Alvaro Morcilo-Laiz for this observation.

\section{References}

Abraham J and Davis C (2011) Rethinking innovation accounting in pharmaceutical regulation: A case study in the deconstruction of therapeutic advance and therapeutic breakthrough. Science, Technology and Human Values 36(6): 791-815.

Bechmann G (2003) The rise and crisis of scientific expertise. In: Bechmann G and Hronzsky I (eds) Expertise and Its Interfaces. Berlin: Edition Sigma, 17-33.

Beck S (2012) Between tribalism and trust: The IPCC under the "public microscope." Nature and Culture 7(2): 151-172.

Beck U (1992) Risk Society. London: Sage.

Bertsch McGrayne S (2011) The Theory That Would Not Die. New Haven: Yale University press.

Bhatt J (2018) Politics by other means: Economic expertise, power and global development finance reform. PhD Thesis, Columbia University, New York.

Bijker WE, Bal R and Hendriks R (2009) The Paradox of Scientific Authority: The Role of Scientific Advice in Democracies. Cambridge, MA: MIT Press.

Bohme G and Stehr N (1986) The Knowledge Society: The Growing Impact of Scientific Knowledge on Social Relations. Boston, MA: D. Reidel Publishing.

Bourdieu P (1987) Legitimation and structured interests in Weber's sociology of religion. In: Lash S and Whimster S (eds) Max Weber, Rationality and Modernity. London: Allen \& Unwin, $119-136$.

Bourdieu P (2000) Pascalian Meditations. Cambridge: Polity Press.

Breyer S (1993) Breaking the Vicious Circle: Towards Effective Risk Regulation. Cambridge, MA: Harvard University Press.

Callon M, Lascoumes P and Barthe Y (2009) Acting in an Uncertain World: An Essay on Technical Democracy. Cambridge, MA: The MIT Press.

Campbell JL and Pedersen OK (2014) The National Origins of Policy Ideas. Princeton, NJ: Princeton University Press.

Carpenter D (2010) Reputation and Power. Princeton, NJ: Princeton University Press.

Cartwright N and Deaton A (2016) Understanding and misunderstanding randomized controlled trials. NBER Working Paper Series No 22595. Available at: https://www.nber.org/papers /w22595

Collins F (2006) The Language of God: A Scientist Presents Evidence for Belief. New York: The Free Press.

Conway E and Oreskes N (2010) Merchants of Doubt. New York: Bloomsbury Press.

Daston L and Galison P (1992) The image of objectivity. Representations 40: 81-128.

Decoteau C and Underman K (2015) Adjudicating non-knowledge in the autism omnibus proceedings. Social Studies of Science 45(4): 471-500. 
Demortain D (2011) Scientists and the Regulation of Risk: Standardizing Control. Cheltenham: Edward Elgar.

Dewey J (1922) Human Nature and Conduct. New York: Henry Holt.

Douglas M (1990) Risk as a forensic resource. Daedalus 119(4): 1-16.

Editorial (2010) Closing the climategate. Nature 468(10): 345.

Edwards P (2010) A Vast Machine: Computer Models, Climate Data and the Politics of Global Warming. Cambridge, MA: MIT Press.

Eliaeson S (2000) Constitutional Caesarism: Weber's politics in their German context. In: Turner S

(ed.) The Cambridge Companion to Weber. Cambridge: Cambridge University Press, 131-148.

Epstein S (1995) The construction of lay expertise: AIDS activism and the forging of credibility in the reform of clinical trials. Science, Technology and Human Values 20(4): 408-437.

Eyal G (2002) Dangerous liaisons: The relations between military intelligence and middle eastern studies in Israel. Theory and Society 31(5): 653-693.

Eyal G (2006) The Disenchantment of the Orient: Expertise about Arab Affairs and the Israeli State. Stanford, CA: Stanford University Press.

Ezrahi Y (1990) The Descent of Icarus: Science and the Transformation of Contemporary Democracy. Cambridge, MA: Harvard University Press.

Foucault M (1998) Preface to transgression. In: Rabinow P (ed) Aesthetics, Method and Epistemology, Essential Works of Michel Foucault, 1954-1984, vol. 2. New York: The New Press.

Friedrich CJ (1972) Tradition and Authority. New York: Praeger Publishers.

Gieryn TF (1983) Boundary work and the demarcation of science from non-science: Strains and interests in professional ideologies of scientists. American Sociological Review 48: 781-795.

Golan T (2004) Laws of Men and Laws of Nature: The History of Scientific Expert Testimony in England and America. Cambridge, MA: Harvard University Press.

Gouldner A (1976) The dark side of the dialectic: Towards a new objectivity. Sociological Inquiry 46(1): 3-15.

Gueron JM and Rolston H (2013) Fighting for Reliable Evidence. New York: Russell Sage Foundation.

Habermas J (1973) Legitimation Crisis. Cambridge: Polity Press.

Jasanoff S (1989) The problem of rationality in American health and safety regulation. In: Smith $\mathrm{R}$ and Wynne B (eds) Expert Evidence: The Interpretation of Science in Law. London: Routledge, 151-183.

Jasanoff S (1990) The Fifth Branch: Science Advisers as Policymakers. Cambridge, MA: Harvard University Press.

Jasanoff S (1995) Science at the Bar: Law, Science, and Technology in America. Cambridge, MA: Harvard University Press.

Jasanoff S (2002) Science and the statistical victim: Modernizing knowledge in breast implant litigation. Social Studies of Science 32(1): 37-69.

Jasanoff S (2003) Technologies of humility: Citizens' participation in governing science. Minerva 41(3): 223-244.

John S (2018) Epistemic trust and the ethics of science communication: Against transparency, openness, sincerity and honesty. Social Epistemology 32(2): 75-87.

Latour B (1993) We've Never Been Modern. Cambridge, MA: Harvard University Press.

Latour B (2010) The Making of Law: An Ethnography of the Conseil D'Etat. Cambridge: Polity Press.

Leao LS and Eyal G (2019) The rise of randomized controlled trials in international development in Historical Perspective. Theory and Society 48(3): 383-418.

Levi-Strauss C (1963) Structural Anthropology. New York: Basic Books.

Medvetz T (2012) Think Tanks in America. Chicago, IL: University of Chicago Press. 
Mitchell T (1991) The limits of the state: Beyond statist approaches and their critics. American Political Science Review 85(1): 77-96.

Mommsen W (1984) Max Weber and German Politics, 1890-1920. Oxford: Blackwell.

O'Kelly R (1989) Prescribing diseases: The industrial injuries advisory council. In: Smith R and Wynne B (eds) Expert Evidence: The Interpretation of Science in Law. London: Routledge, $131-150$.

Parker I (2010) The poverty lab. The New Yorker, 17 May. Available at: http://www.newyorker .com/magazine/2010/05/17/the-poverty-lab (accessed 2 May 2017).

Porter TM (1995) Trust in Numbers: The Pursuit of Objectivity in Science and Public Life. Princeton, NJ: Princeton University Press.

Prior L (2003) Belief, knowledge and expertise: The emergence of the lay expert in medical sociology. Sociology of Health and Illness 25: 41-53.

Proctor RN and Schiebinger L (2008) Agnotology: The Making and Unmaking of Ignorance. Stanford, CA: Stanford University Press.

Rowan KE (1994) The technical and democratic approaches to risk situations: Their appeal, limitations and rhetorical alternative. Argumentation 8: 391-409.

Schaffer S and Shapin S (1985) Leviathan and the Air-Pump: Hobbes, Boyle and the Experimental Life. Princeton, NJ: Princeton University Press.

Stehr N (1994) Knowledge Societies. London: Sage.

Szelenyi I (2016) Weber's theory of domination and post-communist capitalisms. Theory and Society 45: 1-24.

Turner S (2014) The Politics of Expertise. New York: Routledge.

Wacquant LJD (1992) Towards a social praxeology: The structure and logic of Bourdieu's sociology. In: Bourdieu P and Wacquant LJD (eds) An Invitation to Reflexive Sociology. Chicago, IL: The University of Chicago Press, 1-60.

Weber M (1946 [1915]) Religious rejections of the world and their directions. Gerth HH and Mills CW (eds) From Marx Weber: Essays in Sociology. New York: Oxford University Press, 323-359.

Weber M (1946 [1918]) Science as a vocation. In: Gerth HH and Mills CW (eds) From Marx Weber: Essays in Sociology. New York: Oxford University Press, 129-156.

Weber M (1949 [1904]) Objectivity in social science and social policy. In: Shils E and Finch HA (eds) The Methodology of the Social Sciences. New York: The Free Press, 49-112.

Weber M (1978) Economy and Society, vol. I (ed G Roth and C Wittich). Berkeley, CA: University of California Press.

Weber M (1991 [1922]) The Sociology of Religion. Boston: Beacon Press.

Weinberg A (1972a) Science and trans-science. Minerva 10(2): 209-222.

Weinberg A (1972b) Science and trans-science. Science 177(4045): 211.

Weingart P (2003) Paradoxes of scientific advising. In: Bechmann G and Hronzsky I (eds) Expertise and Its Interfaces. Berlin: Edition Sigma, 53-89.

\section{Author biography}

Gil Eyal is professor of Sociology at Columbia University. He is the author of The Crisis of Expertise, a book forthcoming with Polity Press in 2019. 